\title{
EXPECTATIONS ON CHESS, COMPUTER CHESS AND AEGON
}

\author{
H J van den Herık
}

Maastricht, The Netherlands

The $11^{\text {th }}$ AEGON Man-Machine tournament was opened by Jaap van den Herık with the opening address entitled Expectation on Chess, Computer Chess and AEGON An edited version follows below

"With the $11^{\text {th }}$ AEGON tournament, we enter a new decade Up to now, computer chess has had to fight for its position in the world of chess, and computer-chess research results were needed to stimulate both sides of this fundamental research The World of Grandmasters and The World of Artıficial Intelligence Let me start with the AI side "

"Ever since Shannon and Turing, two important contributors to AI, started their computer-chess work in 1950s, the curve of playing strength has increased But up to 1985 this increase, although considerable, has been in the lower classes of the FIDE ratıng system It has been a pleasure for me to notice that, since the start of the AEGON tournament in 1985, the strength of chess computers has reached, successively, national master strength and international master strength It has now even arrived at the level of grandmaster strength The AEGON tournaments have been very instrumental in this success and, on behalf of the ICCA, I thank AEGON, and especially the tournament's initiator Cock de Gorter, for the effort spent in organizing this series of tournaments "

"In the decade just passed, the AEGON tournaments have formed the yardstick for the chess-computer performances and they have been the medication for the sceptics Moreover, AEGON has been the prominent instance showing that chess is pivotal for a company to encourage their workers and their management alıke "

"As Dr Kees Storm has sald durıng the opening ceremony of this afternoon's session, Chess, with its searching technıques, with its techniques for knowledge representation, and with its abstraction methods, forms a guidelıne for handlıng knowledge in companıes, for carryıng out busıness strategies and for findıng the appropriate resources in the right tıme period The message is clear Computers are fit for difficult tasks, they are quick, supportive and ubiquitous Moreover, they are automatons that are almost as intelligent as human beings"

"The start of AI research was on games (CHESS and CHECKERS), in mathematics (theorem proving), and in linguistics (automatic translation), but now this research spans almost all domains of intelligent behaviour I can mention logistics, routıng, planning, prediction, diagnosis, private bankıng, advice systems for policy and mortgage Next to intelligent programs, nowadays we also see their combination with communication and communication protocols This development has broadened computer science (also called informatics) to telecommunications As a consequence, we now have intelligence at our disposal via Internet without regard to location "

"At the press conference Mr Peverellı informed us that the three matches of this afternoon are being watched by over 15,000 people from 42 countries (to provide you only with an observation at $5 \mathrm{p} \mathrm{m}$ )"

"Optımists such as researcher Donald Michie foresee the day when poverty, hunger disease, and political strive have been tamed through the use of knowledge, the product of computers actıng as our assistants, not as our slaves "

"The last example brings me back to the world of chess and to the topic of this evening Grandmasters, Masters and 'amateur chess-players', men and women together, I am delighted to welcome you all at this eleventh AEGON tournament Although all chess-players have their famous moments, I would like to make three exceptions and give them a special welcome with an applause They are World Champion Anatoli Karpov, almost World Champion David Bronsteın, and to make it a little more balanced, Hans Berlıner, the 
former World Correspondence-Chess Champion and Computer Chess researcher "

"Chess-players, you will be confronted with 50 machines in the next six rounds to come But be careful, your results will not be as good as those of the three Grandmasters of this afternoon namely Karpov-FriTZ $1 \frac{1}{2}-1 / 2$, Timman-MCHESS PRO 1-1 and Piket-THE KING for an overall $75 \%$ score "

"Although my list may go too far, let us review some of the seminal products of computer-chess research They are search techniques, knowledge representation and manıpulation, exhaustıve databases, thınkıngaloud protocols (due to Simon and De Groot), transposition tables, pattern recognizers, learning concepts, and opponent modelling (for chess, economy and war games) "

"In the invitation for this tournament, it was stated that my speech would be on tournament expectations and I will give them now I provide you with three expectations, namely for this yeal, being 1996, for 1998 and for 1999 "

"First, the tournament contains 100 partıcıpants, equally divided between humans and machınes, playıng 6 rounds This implies that there will be 300 games all together My educated guess is that the final result will be in balance, this means $150-150$ But when pressed to take a position, my prediction is $160-140$ for the computers Indeed, I will not be surprised if the odds are reversed, but if the computers score fewer than 140 points I will be a little disappointed Moreover, I expect three computers to land among the first eight places To be more precise, I believe that these will be three out of the following seven FRITZ, MCHESS Pro, The King, Chess Genius, Hitech, Rebel and HiarCs "

"My second expectation concerns the $13^{\text {th }}$ AEGON tournament in 1998 Not for its number, not for the assumed contınuation - that will be sure I think - but for its result I believe that in 1998 the computers will sweep the floor with Masters, Grandmasters and World top players alıke "

"This immediately brings me to the my third expectation An overwhelming victory for the computers in 1998, which is foreseeable already now, will have a big impact on the Management Meetıngs of the AEGON Board They are the world leaders in human-computer events now, but then they have to set new guidelınes and to develop new plans for their $14^{\text {th }}$ tournament in 1999 The best advice I can give them here is to start already now thınkıng about a new approach of theır beloved formula of man-versus-machine meetıngs Maybe Kasparov's idea of man-combined-with-machıne tournaments is an idea to probe in reality But I am sure there are many more possibilities to look for I only mention specific opening sequences, points for providing the longest resistance, handicapping the computer in one or another way, for instance by allottıng differences in thinkıng tıme, etc "

"I believe the capacity of the human mind for settıng rules is inexhaustıble However, the message of my speech is that machines themselves conceive solutions that have eluded human minds For chess, this is recognized and soon it will be a proven truth For judgements, laws and regulations it is still under investigation But I will not dwell on this topic here "

"With this $11^{\text {th }}$ AEGON tournament, we are, I think, on the threshold of a chess renaissance, another golden age, with big changes where humans use computer assistants I am aware of the personal confession of $\mathrm{Dr}$ Kees Storm, in quotation "Personally, I would find it hard to come to terms with the idea that the computer can beat man at this magnificent, centuries-old game ," and then he gave his explanation But I will try to convince him after this speech that this development is natural, and that even with computers we will never find the truth Chess is a game for man and machines It will never lose its glamour and will remain as challenging as doing such business as running an insurance company "

"Finally, I would like to thank AEGON, its management, its workers and all other assistants who have made this $11^{\text {th }}$ tournament possible, bigger, larger and greater than before and, without question, the best humancomputer contest in the world Although backıng the computers, I wish the human chess-players a good tournament, especially since the humans understand me, but for computers this will take a long time " 